\title{
Evektifitas Penyinaran Untuk Peningkatan Produksi Buah Naga
}

\section{Lighting Effectiveness to Increase Dragon Fruits Production}

\author{
Cindy Ineke Ferdianti ${ }^{1}$, Sudarti ${ }^{2}$ \\ ${ }^{1}$ Mahasiswa Program Studi Pendidikan Fisika, Universitas Jember Jl. Kalimantan Tegalboto, Krajan Timur, Sumbersari, \\ Kabupaten Jember, Jawa Timur, Indonesia \\ ${ }^{2}$ Tenaga Pendidik Program Studi Pendidikan Fisika, Universitas Jember Jl. Kalimantan Tegalboto, Krajan Timur, \\ Sumbersari, Kabupaten Jember, Jawa Timur, Indonesia \\ Email: cindyinekeferdianti@gmail.com, Sudarti.fkip@unej.ac.id
}

Article Submitted : 19-11-2021

Article Accepted : 22-12-2021

\begin{abstract}
Dragon fruit has a fairly high economic value, but its productivity is still seasonal, so it can be harvested at the same time lowering prices. This study aims to test the effectiveness of lighting in increasing the productivity of dragon fruit. This research was conducted through a survey with respondent dragon fruit farmer who use lighting and not. The sample of this research is dragon fruit tree which consists of 50 trees that are illuminated and 50 trees that are not. As an indicator of dragon fruit productivity, dragon fruit and flowers were counted during the study. The research data were analyzed using T-Test analysis to produce dragon fruit tree productivity between the two sample groups. The results of 'this study showed that the productivity of dragon fruit in the without lighting group produced an average of 4 fruits and in the lighting group produced an average of 8 fruits. Flower productivity in the without lighting group produced an average of 6 flowes and in the lighting group an average of 21 flowers. Giving light in dragon fruit farming is effective in increasing productivity.

Keyword: Dragon fruit, lighting, productivity
\end{abstract}

\section{PENDAHULUAN}

Tanaman buah naga merupakan tanaman sejenis kaktus yang berasal dari Meksiko, Amerika Tengah dan Amerika Selatan. Di masa sekarang, tanaman buah naga sudah banyak dibudidayakan di negara-negara Asia seperti Vietnam, Malaysia, Filipina, hingga Indonesia. Tanaman buah naga termasuk ke dalam tanaman musiman, yang tidak berbuah sepanjang tahun. Menurut Susanto dan Rondhi (2021), tanaman buah naga mulai berbunga pada saat awal musim penghujan. Tanaman buah naga akan berbuah lebat saat mencapai umur dewasa. Harga buah naga di musim panen akan menurun, jika dibandingkan dengan harga buah naga di luar musim panen. Hal tersebut dikarenakan pada saat musim panen, produktivitas buah naga yang melimpah melebihi permintaan pasar, sehingga harga buah naga lebih rendah. Ketika di luar musim, maka produktivitas buah naga lebih kecil daripada permintaan, sehingga harga buah naga menjadi tinggi.

Tanaman buah naga memiliki dampak terhadap kehidupan masyarakat. Diantaranya pertanian buah naga menyediakan sumber penghasilan untuk menyambung hidup, memenuhi kebutuhan nutrisi yang baik untuk masyarakat, menyediakan tanaman alternatif bagi petani yang terdampak perubahan lingkungan, memperkuat kemitraan antara pemerintah, LSM, dan swasta, menciptakan lapangan mata pencaharian (Pascua et al., 2015). Menurut Kristriandiny dan Slamet (dalam Paundrianagari et al., 2019) pengembangan agribisnis buah naga memiliki prospek yang cemerlang dalam ekspor untuk pasar luar negeri, serta memiliki potensi yang baik untuk pasar di dalam negeri. Kebutuhan akan buah naga cukup tinggi, sehingga kesempatan untuk membudidayakan buah naga masih terbuka lebar (Sintia et al., 2018). Secara komersial, buah naga memiliki nilai jual yang dapat dikatakan tinggi, buah naga menarik dalam bentuk dan warna dan juga kandungan nutrisi yang baik (Perween et al., 2018).

Para petani buah naga menemukan inovasi berupa pemasangan lampu pada tanaman buah naga. Menurut Firdaus et al., (2019) pemasangan lampu pada tanaman buah naga dimaksudkan untuk meningkatkan produksi buah naga. Hal ini berkaitan dengan buah naga yang berbunga hanya di malam hari (night blooming cereus). Ketika dengan bantuan lampu maka tanaman buah naga dapat berbuah di luar musim. Penyinaran lampu pada malam hari berdampak pada pembukaan stomata yang semakin optimal. Hal tersebut menyebabkan laju pengambilan $\mathrm{CO} 2$ untuk fotosintesis meningkat sehingga terjadi penambahan periode fotosintesis, dan memungkinkan iniaiasi primordia bunga di bagian meristem. Untuk hasil yang lebih cepat dalam menstimulasi kuncup bunga, dapat dengan menggunakan lampu LED dengan intensitas cahaya yang lebih tinggi (Saputra dan Wiraatmaja, 2020).

Teknik pemasangan lampu pada tanaman buah naga, umumnya ada 2 cara. Cara pertama yakni dengan sistem 4-1 (4 pohon disinari 1 lampu) dan cara kedua dengan sistem 2-1 (2 pohon disinari 1 lampu). Dengan adanya pemasangan tersebut 
dapat menjamin ketersediaan buah naga di pasaran (Hadi dan Sartika, 2019).

Penelitian ini bertujuan mengkaji efektivitas penyinaran untuk meningkatkan produktivitas buah naga. Produksi yang dimaksud dalam penelitian ini berupa jumlah buah dan bunga pada tanaman buah naga. Peneliti berharap hasil dari penelitian ini dapat menginspirasi para petani buah naga pada khususnya, serta masyarakat luas pada umumnya.

\section{METODE}

Penelitian ini dilaksanakan di Desa Kembiritan, Kecamatan Genteng, Kabupaten Banyuwangi, tepatnya pada tanggal 1 November 2021. Penelitian ini dilaksanakan melalui survey dengan responden petani buah naga yang tidak menggunakan penyinaran lampu dan menggunakan penyinaran lampu. Sampel penelitian ini adalah pohon buah naga yang terdiri dari 50 pohon yang mendapat penyinaran lampu dan 50 pohon yang tidak mendapat penyinaran lampu. Sebagai indikator produktivitas buah naga, maka dilakukan perhitungan buah naga beserta bunga yang telah muncul saat penelitian. Data penelitian di analisis menggunakan analisis T-Test untuk membandingkan produktivitas pohon buah naga antara 2 kelompok sampel tersebut.

Penelitian ini menggunakan analisis T-test untuk mengetahui ada atau tidaknya perbedaan ratarata dua sampel yang tidak saling berpasangan. Dengan analisis T-test ini dapat diketahui perbedaan rata-rata jumlah buah naga dengan penyinaran lampu dan tanpa penyinaran lampu, serta perbedaan rata-rata jumlah bunga tanaman buah naga dengan penyinaran lampu dan tanpa penyinaran lampu. Dasar pengambilan keputusan dalam uji independent sample $T$-test ialah sebagai berikut:

Perumusan hipotesis

H0: Tidak ada perbedaan jumlah buah/bunga tanaman buah naga antara dengan penyinaran lampu dan tanpa penyinaran lampu

Ha: Ada perbedaan jumlah buah/bunga tanaman buah naga antara dengan penyinaran lampu dan tanpa penyinaran lampu

Dasar pengambilan keputusan

Jika Asymp Sig. < 0,05 maka H0 ditolak

Jika Asymp Sig. > 0,05 maka H0 diterima

\section{HASIL DAN PEMBAHASAN}

Penyinaran lampu pada tanaman buah naga merupakan bukti nyata inovasi di kalangan petani yang semakin berkembang maju. Ide penyinaran lampu pada tanaman buah naga ini awalnya hanya di terapkan oleh beberapa petani saja, kemudian saat melihat hasil produksi buah naga dengan penyinaran lampu lebih maksimal membuat para petani lain ikut tergerak untuk menerapkan penyinaran lampu. Para petani sadar bahwa dengan adanya penyinaran pada tanaman buah naga dapat menjadikan tanaman buah naga berbuah tanpa mengenal musim. Jika sebelumnya para petani memperoleh panen saat musim buah naga saja, namun dengan adanya pemasangan lampu menyebabkan tanaman buah naga dapat panen sepanjang tahun.

Tahap pengumpulan data yang pertama adalah wawancara. Peneliti bertanya mengenai modal awal penanaman buah naga. Hasil wawancara dapat ditunjukkan pada tabel berikut.

Tabel 1. Transkrip wawancara

\begin{tabular}{ll}
\hline Kode & Pertanyaan/Jawaban \\
\hline P01 & Berapakah modal awal yang dikeluarkan untuk tanaman buah naga dengan \\
& penyinaran lampu dan tanpa penyinaran lampu, Mas? \\
\hline J01 & Harga cagak randu Rp. 2.000 untuk satuannya dan harga bibit buah naga Rp. 1.000 \\
& untuk satu lanjar. Untuk yang tanpa penyinaran lampu modal awal hanya \\
& menyiapkan cagak randu dan bibit saja. Sedangkan untuk yang menggunakan \\
& penyinaran modal awalnya yaitu menyiapkan cagak randu, bibit, kabel, pitingan, \\
& skakel, dan lampu, menghabiskan biaya sebesar Rp. 5.000 .000 untuk 50 pohon. \\
\hline
\end{tabular}

Berdasarkan transkrip di atas, biaya yang dikeluarkan untuk modal awal antara tanaman buah naga dengan penyinaran lampu dan tanpa penyinaran lampu sangat berbeda. Modal awal tanaman buah naga tanpa penyinaran lampu relatif lebih murah, karena hanya bermodalkan cagak randu dan bibit tanaman buah naga. Harga satuan cagak randu yaitu Rp. 2.000 dan harga bibit buah naga per lanjarnya yatu Rp. 1000. Sehingga untuk 50 tanaman buah naga menghabiskan biaya sebesar Rp. 150.000. Sedangkan untuk modal awal untuk 50 tanaman buah naga menggunakan penyinaran lampu meliputi cagak randu, bibit, kabel, pitingan, skakel, dan lampu menghabiskan biaya sebesar Rp. 5.000.000. Perbedaan biaya awal yang dikeluarkan untuk buah naga tanpa penyinaran dan dengan penyinaran dapat dikatakan berbeda jauh, yakni sebesar Rp. 4.850.000.

Pada tahap wawancara, peneliti juga bertanya mengenai perawatan tanaman buah naga. Hasil dari wawancara ditunjukkan pada tabel berikut. 
Tabel 2. Transkrip wawancara

\begin{tabular}{ll}
\hline Kode & Pertanyaan/Jawaban \\
\hline P02 & $\begin{array}{l}\text { Perawatan tanaman buah naga ini meliputi apa saja? Dan bagaimana perbedaan } \\
\text { perawatan antara tanaman buah naga tanpa penyinaran dan dengan penyinaran? }\end{array}$ \\
\hline J02 & $\begin{array}{l}\text { Kalo tanpa penyinaran lampu nutrisi sedikit dan pupuk secukupnya. Tapi sebaliknya } \\
\text { untuk penyinaran lampu, pupuk dan nutrisi harus ekstra mencukupi karena buah naga } \\
\text { berbuah di luar musim ibarat orang kerja itu lemburannya dan harus dikasih makan } \\
\text { pagi sampai malam (contoh saja). }\end{array}$ \\
\hline
\end{tabular}

Dari transkrip diatas untuk perawatan buah naga dengan penyinaran lampu dan tanpa penyinaran lampu memiliki perbedaan. Perbedaan terletak pada pemberian nutrisi dan pupuk. Pada tanaman buah naga tanpa penyinaran lampu, pemberian nutrisi dan pupuk diberikan secukupnya. Sedangkan pada tanaman buah naga dengan penyinaran lampu pemberian nutrisi dan pupuk harus ekstra. Hal tersebut karena tanaman buah naga harus berbuah di luar dari musim seharusnya berbuah.

Peneliti juga bertanya mengenai produksi buah naga. Hasil wawancara dapat ditunjukkan pada tabel berikut.

Tabel 3. Transkrip wawancara

\begin{tabular}{ll}
\hline Kode & Pertanyaan/Jawaban \\
\hline P03 & $\begin{array}{l}\text { Lalu } 1 \text { pohon biasanya menghasilkan berapa kg ya mas? (Saat tanpa penyinaran dan } \\
\text { dengan penyinaran) }\end{array}$ \\
\hline J03 & Tergantung perawatannya. Jika tanpa penyinaran lampu, nutrisi dan pupuk hanya \\
& diberikan secukupnya. Jika menggunakan lampu maka nutrisi dan pupuk harus ekstra \\
& karena tanaman buah naga berbuah di luar musim. Bantuan penyinaran lampu dapat \\
& membantu fotosintesis dan merangsang pertumbuhan bunga. Ketika tanpa bantuan \\
& penyinaran lampu satu pohon sekitar $5 \mathrm{~kg}$ dan ketika dengan bantuan penyinaran \\
& lampu satu pohon sekitar $10 \mathrm{~kg}$. \\
\hline
\end{tabular}

Berdasarkan transkrip tersebut, dapat diketahui bahwa hasil produksi tanaman buah naga tergantung pada perawatannya. Perawatan yang dimaksud disini ialah pemberian nutrisi dan juga pupuk. Pada tanaman buah naga tanpa penyinaran lampu maka nutrisi dan pupuk diberikan secukupnya saja. Sedangkan pada tanaman buah naga dengan penyinaran lampu nutrisi dan pupuk diberikan secara ekstra. Hal ini disebabkan dengan sinar lampu yang membantu proses fotosintesis dan merangsang pertumbuhan bunga. Pertumbuhan bunga yang banyak menyebabkan nutrisi dan pupuk yang diberikan harus ekstra agar buahnya bisa maksimal. Sehingga pada umumnya tanaman buah naga yang menggunakan penyinaran lampu dalam satu pohonnya menghasilkan produksi buah yang lebih tinggi, jika dibandingkan tanpa penyinaran lampu. Satu pohon buah naga tanpa penyinaran lampu dapat menghasilkan sekitar $5 \mathrm{~kg}$ buah dan satu pohon buah naga dengan penyinaran lampu dapat menghasilkan sekitar $10 \mathrm{~kg}$ buah.

Selanjutnya peneliti bertanya mengenai frekuensi panen tanaman buah naga kepada petani buah naga. Hasil wawancara dapat ditunjukkan pada tabel berikut

Tabel 4. Transkrip wawancara

\begin{tabular}{ll}
\hline Kode & Pertanyaan/Jawaban \\
\hline P04 & $\begin{array}{l}\text { Dalam setahun bisa panen berapa kali mas? (saat tanpa penyinaran dan dengan } \\
\text { penyinaran) }\end{array}$ \\
\hline J04 & $\begin{array}{l}\text { Buah naga buah yang bisa di buahkan setiap bulannya, buah naga butuh waktu 2 } \\
\text { bulanan dari mulai keluar calon buah sampai panen dan juga itu buah naga tanaman } \\
\text { yang bisa berumur hingga puluhan tahun dan hanya regenerasi sulur/turus naga yang } \\
\\
\text { tua saja. Kalau tanpa penyinaran lampu biasanya panen minim hingga } 5 \text { kali dalam } \\
\text { setahun. Kalau dengan penyinaran biasanya panen minim } 10 \text { kali dalam setahun }\end{array}$ \\
\hline
\end{tabular}

Berdasarkan transkrip diatas, buah naga merupakan tanaman yang dapat berbuah setiap bulan. Tanaman buah naga membutuhkan waktu selama 2 bulan dari mulai keluar calon buah hingga sampai panen. Tanaman buah naga juga merupakan tanaman berumur panjang, bahkan hingga puluhan tahun. Masa panen tanaman buah naga tanpa penyinaran lampu dan dengan penyinaran lampu berbeda. Jika tanpa penyinaran, dalam waktu satu tahun bisa panen paling sedikit 5 kali dan jika dengan penyinaran lampu, dalam waktu satu tahun bisa panen paling sedikit 10 kali. Dengan perbedaan ini maka dapat diketahui bahwa produksi tanaman buah naga dengan menggunakan penyinaran 2 kali 
lipat lebih tinggi dibandingkan produksi tanaman buah naga tanpa penyinaran.

Tahap pengumpulan data berikutnya adalah perhitungan produksi tanaman buah naga. Produksi tanaman buah naga yang menjadi objek penelitian yaitu buah dan bunga. Sehingga dapat diketahui ada atau tidaknya perbedaan produksi tanaman buah naga dengan bantuan lampu dan tanpa bantuan lampu. Hasil dari pengumpulan data disajikan dalam tabel berikut menggunakan Independent Samples Test.

Tabel 5. Hasil Independent Samples Test

\begin{tabular}{|c|c|c|c|c|c|c|}
\hline & & $\mathrm{F}$ & Sig. & $\mathrm{T}$ & Df & $\begin{array}{l}\mathrm{Sg} .(2- \\
\text { tailed) }\end{array}$ \\
\hline \multirow{7}{*}{$\begin{array}{l}\text { Hasil } \\
\text { Jumlah } \\
\text { Bunga }\end{array}$} & Equal & 7,163 & ,009 & 29,885 & 98 & ,000 \\
\hline & variances & & & & & \\
\hline & assumed & & & & & \\
\hline & Equal & & & 29,885 & 85,494 &, 000 \\
\hline & variences & & & & & \\
\hline & not & & & & & \\
\hline & assumed & & & & & \\
\hline
\end{tabular}

Berdasarkan output diatas, diketahui terdapat dua taraf signifikansi, yakni Equal variances assumed dan Equal variances not assumed. Nilai taraf signifikansi $\mathrm{F}$ yaitu sebesar 0,009 yang artinya lebih kecil dari 0,05 . Sehingga varian populasi jumlah bunga tanaman buah naga dengan lampu dan tanpa lampu tidak identik (Equal variances not assumed). Signifikansi F-hitung memiliki keputusan Equal variances not assumed, sehingga t test tersebut juga menggunakan dasar Equal variances not assumed. Nilai signifikansi 2-tailed sebesar 0,00 sehingga dapat diketahui bahwa tolak H0 terima Ha. Artinya ada perbedaan yang signifikan jumlah bunga tanaman buah naga antara dengan lampu dan tanpa lampu. Jumlah bunga pada tanaman buah naga tanpa lampu paling sedikit yaitu 4 dan paling banyak yaitu 10. Rata-rata jumlah bunga pada tanaman buah naga tanpa penyinaran yakni sejumlah 6 . Jumlah bunga pada tanaman buah naga dengan penyinaran paling sedikit yaitu 15 dan paling banyak yaitu 26. Rata-rata jumlah bunga pada tanaman buah naga menggunakan penyinaran lampu yakni sejumlah 21. Dari hasil tersebut maka dapat diketahui jumlah bunga pada tumbuhan buah naga dengan bantuan penyinaran lampu lebih banyak daripada tanpa bantuan penyinaran lampu.

Tabel 6. Hasil Independent Samples Test

\begin{tabular}{|c|c|c|c|c|c|c|}
\hline & & $\mathbf{F}$ & Sig. & $\mathbf{T}$ & Df & $\begin{array}{l}\text { Sg. (2- } \\
\text { tailed) }\end{array}$ \\
\hline \multirow[t]{2}{*}{$\begin{array}{l}\text { Hasil } \\
\text { Jumlah } \\
\text { Bunga }\end{array}$} & $\begin{array}{l}\text { Equal } \\
\text { variances } \\
\text { assumed }\end{array}$ & 1,232 & ,270 & 9,600 & 98 & ,000 \\
\hline & $\begin{array}{l}\text { Equal } \\
\text { variences } \\
\text { not } \\
\text { assumed }\end{array}$ & & & 9,600 & 95,946 & ,000 \\
\hline
\end{tabular}

Nilai signifikansi 2-tailed sebesar 0,00 sehingga dapat diketahui bahwa tolak H0 terima Ha. Artinya ada perbedaan yang signifikan jumlah bunga tanaman buah naga antara tanpa penyinaran dan dengan penyinaran. Jumlah buah pada tanaman buah naga tanpa lampu paling sedikit yaitu 2 dan paling banyak yaitu 8 . Rata-rata jumlah buah naga tanpa penyinaran yakni sejumlah 4. Jumlah buah pada tanaman buah naga dengan lampu paling sedikit yaitu 5 dan paling banyak yaitu 13 . Rata-rata jumlah buah naga dengan penyinaran yakni sejumlah 8. Dari hasil tersebut maka dapat diketahui jumlah buah pada tanaman buah naga dengan bantuan penyinaran lampu lebih banyak daripada tanpa bantuan penyinaran lampu.

\section{KESIMPULAN}

Penyinaran lampu efektif untuk meningkatkan hasil produktivitas tanaman buah naga. Jumlah rata-rata bunga dan buah pada tanaman buah naga yang diberi penyinaran lampu lebih banyak daripada yang tanpa penyinaran lampu. Meskipun biaya awal yang dikeluarkan untuk tanaman buah naga dengan bantuan lampu lebih mahal, namun kuantitas produksi dan frekuensi panennya lebih tinggi daripada tanaman buah naga tanpa penyinaran.

\section{DAFTAR PUSTAKA}

Firdaus, H., Indriani, dan Slamet. 2019. Sukses Berkebun Buah Naga Dengan Teknik Penyinaran Listrik Di Kabupaten Banyuwangi. JurnalSeniati. 1(1):363-369 
Hadi, C. F. dan D. Sartika. 2019. Rancang Kendali Berbasis Android Pada Penyinaran Kebun Buah Naga. Jurnal SinarFe7. 1(1):171-174

Pascua, L. T., M. E. Pascua, dan M. L. S.Gabriel. 2015. Dragon Fruit Production And Marketing In The Phillipines: Its Status, Constrains and Prospects. Inproving Pitaya Production and Marketing International Journal. 1(1):47-63

Paundrianagari, S. A., N. Saetyowati, dan R. A. Qanita. 2019. Strategi Pengembangan Agribisnis Buah Naga Organik di Kabupaten Wonogiri. Jurnal SEA. 8(2):5566

Perween, T., K. Mandal, dan M. A. Hasan. 2018. Dragon Fruits: An Exotic Super Future Fruit of India. Journal of Pharmacognosy and Phytochemistry. 7(2): 1022-1026
Saputra, A. D., I. A. Gunadi, dan I. W. Wiraatmaja. 2020. Efek Penggunaan Beberapa Sinar LED pada Tanaman Buah Naga Merah (Hylocereus polyrhizus). Jurnal Agrotrop. 10 (2): 201-210

Sintia, N. L., H. Prayuginingsih, dan F. N. Wijayanti. 2018. Analisis Produktivitas Keuntungan Usaha Tani Buah Naga Berdasarkan Skala Usaha di Kecamatan Tegalsari Kabupaten Banyuwangi. Jurnal Agribest. 2(1):32-38

Susanto, I. D. dan M. Rondhi. 2021. Efek Inovasi Penyinaran Lampu Pada Usahatani Buah Naga di Desa Bulurejo Kecamatan Purwoharjo Kabupaten Banyuwangi. Jurnal Kirana. 1(2):93-103 